\title{
Parental Attachment, Inter-Parental Conflict and Late Adolescent's Self-Efficacy
}

\author{
Nakisa Parsa ${ }^{1}$, Siti Nor Yaacob ${ }^{1}$, Ma'rof Redzuan $^{2}$, Parisa Parsa ${ }^{3} \&$ Nooshin Sabour Esmaeili ${ }^{1}$ \\ ${ }^{1}$ Family, Adolescent and Child Research Centre of Excellent (FACE), Faculty of Human Ecology, University \\ Putra Malaysia (UPM), Malaysia \\ ${ }^{2}$ Department of Social and Development Sciences, Faculty of Human Ecology, University Putra Malaysia \\ (UPM), Malaysia \\ ${ }^{3}$ Research Centre for Chronic Diseases Care at Home, Department of Mother and Child Health, Hamadan \\ University of Medical Sciences, Hamadan, Iran \\ Correspondence: Nakisa Parsa, Family, Adolescent and Child Research Centre of Excellent (FACE), Faculty of \\ Human Ecology, University Putra Malaysia (UPM), Malaysia. E-mail: nakisa15@yahoo.com
}

Received: January 9, 2014 Accepted: February 24, 2014 Online Published: March 26, 2014

doi:10.5539/ass.v10n8p123 URL: http://dx.doi.org/10.5539/ass.v10n8p123

\begin{abstract}
The main purpose of this study was to determine the relationship between parental attachment, inter-parental conflict and self-efficacy among 374 college students aged 17 to 19 years old in Iran. The probability proportional to size sampling technique was used to obtain sample size. The Inventory of Parent and Peer Attachment, the Children's Perception of Inter-parental Conflict Scale, and the General Self-Efficacy Scale were used to measure parental attachment, inter-parental conflict and self-efficacy, respectively. Results of Pearson correlation coefficient showed that parental attachment was positively and inter-parental conflict was negatively associated with adolescent's self-efficacy.
\end{abstract}

Keywords: parental attachment, inter-parental conflict, self-efficacy, adolescent

\section{Introduction}

Adolescence is characterized as a risky and turbulent period of life time (Bandura, 1997). Adolescents face significant amount of changes in physical, emotional and cognitive aspects as well as increasing expectation from family and society (Hazen, Schlozman, \& Beresin, 2008). The sense of self-efficacy is important element to overcome difficulties and success during adolescent's lifetime. Self-efficacy is defined as a personal perceived capability to accomplish specific tasks to achieve the desired results (Bandura, 1997; Ormrod, 2006). Self-efficacy beliefs illuminate how people think, behave and feel (Bandura, 1994). Past research (Bandura, 1997; Caprara, Steca, Cervone, \& Artistico, 2003; Ferla, Valcke, \& Schuyten, 2008; Luszczynska, Gutierrez-Dona, \& Schwarzer et al., 2005) emphasized that adolescent with high self-efficacy tended to have more positive developmental outcomes in physical and mental health, coping efficacy, and academic achievement. Thus, individual with high self-efficacy are more likely to have a greater strategic flexibility, cognitive resourcefulness, and set an encouraging target for themselves and able to control their environment. Individual who believe in their ability, work harder and are more persistent to achieve their goals than those who are unsure about their abilities (Bandura, 1994). However, low self-efficacy has been associated with low academic achievement, depression, anxiety, helplessness as well as negative effects in social and emotional relationships (Bandura, 1996; Goodness, Buhrmester, \& Jenkins, 2002; Zajacova, Lynch, \& Espenshade, 2005). As argued by Murphy, Gaughan, Hume, and Moore (2010) adolescent with a low self-efficacy considers difficult tasks as threats and tries to avoid them. They usually have low aspiration and weak obligation to their goals. They may be overwhelmed with a low sense of efficiency which may leads to negative outcomes that affect general well-being.

Adolescent's self-efficacy is influenced by social factors such as, families, school, and peers (Bandura, 1986). According to social cognitive theory (Bandura, 1986), family is viewed as an initial source of self-efficacy and known as a primary source for adolescent's well-being. Bandura (1986) revealed four sources of information which are including mastery experiences, vicarious experiences, verbal encouragement and physiological status 
that effect on self-efficacy. A person's experience of mastery in the past is the most effective factor in building the sense of self-efficacy. Adolescent learns how to use various sources of efficacy from family, peer and society to develop a steady personal efficacy (Coleman, 2003; Kenny, 1994). Parents who are warmth, responsive, and supportive are more likely to foster trust, competencies and self-efficacy beliefs in adolescent and provide diverse and multiple opportunities for mastery experience (Bandura, 1986). Such beliefs of competence are necessary during transition to different stages of development to help adolescents to cope with the stressful events. Furthermore, adolescents who received encouragement and support from parents develop a strong sense of self independent (Marcia, 1991). According to Bandura (1994), self-efficacy can grow through vicarious experiences by role-modeling and observation of parents, sibling and peer. These changes of behavior and thinking during early to late adolescence, prepare adolescents for independency by gaining more mastery experiences. However, adolescent with low self-efficacy take this inefficiency to the new stage of development (Bandura, 1989).

Compared to social cognitive theory, attachment theory emphasizes the importance of parent-adolescent relationships during adolescence. Attachment is defined as an emotional bond established between an individual and a provider of secure base which help one's to explore the environment (Bowlby, 1982). Adolescent constructs his/her internal working models of what he or she can expect about self based on their relationships with first caregiver especially parents (Bowlby, 1982). Past studies (Allen \& Land, 1999; Cooper, Shaver, \& Collins, 1998; Smetana et al., 2006) shown that adolescents with good attachments to parents have better psychosocial well-being and more knowledgeable in social domain than unsecure adolescents. Cooper et al. (1998) revealed that adolescent with secure attachment had more control on their emotions and better adjustment than those with insecure attachment. Secure attachment is important in the development of self and identity during adolescence (Allen \& Land, 1999). Smetana, Campione-Bafr, and Metzgef (2006) emphasize that in close and warm parent-adolescent relationship, adolescent spend more direct relationship with mothers and talk more about personal issues such as dating. In positive parent-adolescent attachment, mothers provide more emotional support while fathers provide material and informational support (Steinberg \& Silk, 2002). In general, research support that during adolescence, secure attachments with parents linked to high levels of self-esteem and self-efficacy (Arbona \& Power, 2003; Laible, Carlo, \& Roesch, 2004; Thompson, 1999).

Inter-parental conflict is related to parents' withdrawal, reduced parental physical and psychological availability and negative response of their children and adolescent needs (Cummings \& Davies, 1994). Inter-parental conflict negatively effects on family environment and adolescent behavior (Grych \& Fincham, 1993; Oh et al., 2011). Social Cognitive Theory (Bandura, 1989), emphasize that adolescents within the social contexts have vicarious experience with parental conflict through their parents and parent-adolescent relationships. In social modeling, adolescent usually observe and imitate their parents' behavior to make a pattern of conflictive behavior (Bandura, 1997; Pryor \& Pattison, 2007). According to attachment theory inter-parental conflict is related to child maladjustment via it's relation to insecure parent-child attachment (Davies, Harold, Goeke-Morey, \& Cummings, 2002). As children grow up to adolescents this insecure attachment is expressed as anxious ambivalence, avoidance or disorganized (Belsky, 2002). Reese-weber and Kahn, (2005) suggest that late adolescent observe how parents engaged in conflict and resolve the conflict and consequently practices similar behaviors with their siblings, partner and even parents. Research by Sergin, Taylor, and Altman (2005), Platt, Nalbone, Casanova, and Wetchleret (2008), and Collin and Dozois, (2008) showed that inter-parental conflict may be stronger predictor of adolescent negative psychosocial consequences such as depression, low self-efficacy and self-esteem (Burns $\&$ Dunlop, 2002). Inter-parental conflict may effect on the quality of the parent-adolescent relationships such as using harsh discipline and inadequate supervision (Tillman, 2007; Wolf \& Foshee, 2003). Low support may reduce the feeling of independent and sense of self (Buehler, Lange, \& Franck, 2007; Schulz et al., 2005) and increases the chance of parent-adolescent conflict (Risdal \& Singer, 2004; Grych \& Fincham, 1990). As a result, inter-parental conflict may link directly to adolescent's behavior through modeling and exposure to stress and indirectly through changes in the parent-child relationships (Moura, Santos, Rocha, \& Matos, 2010).

Markiewicz, Doyle, and Brendgen (2001) shown that inter-parental conflict in family environment negatively affect adolescent security attachment. Inter-parental conflict reduced mother effectiveness and responsiveness toward adolescent and marginalized father form their children and therefore, reduce his emotional and physical availability (Markiewicz, 2001). Past studies shown that maternal and paternal attachments are positively related to adolescent's emotional adjustment (Rice, Cunningha, \& Young, 1997) and self-efficacy (Bandura, 1986, 1997; Malinckrodt, 1992). However, inter-parental conflict is related to low self-efficacy (Canary \& Canary, 2013; Weber \& O' Brien, 1999) and higher levels of interpersonal and social problem (Endler, Speer, Johnson, \& Flett, 2001; Kolb \& Griffith, 2009; Rynn, Vidair, \& Blackford, 2012). The empirical evidence suggests that 
perceptions of inter-parental conflict and parental attachment are related with one another (Amato \& Sobolewski, 2001; Davies \& Cummings, 1994), and the interaction between these two constructs may effect on adolescent' self-efficacy (Bandura, 1989).

Due to the importance of self-efficacy in general health, academic and occupational success, this study aimed to determine the relationship between parental attachment, inter-parental conflict, and self-efficacy among late adolescents in Iran. Youth are the largest group in Iranian history (Statistical Center of Iran, 2010). More than 35 percent of Iran's populations are between 15-29 years old (Egel \& Salehi-Isfahani, 2010; Ghafari \& Ghasemi, 2007). Ghasemi (2010) and Neghabi and Rafiee (2013) indicated that $22 \%$ of students in Iran suffer personal (e.g., low self-efficacy) and family problem. Previous studies (Azimi, Jannati, \& Mahmoudi, 2002; Sadeghian \& Heidarian, 2009) found a growing number of psychological problems among college students compared to those who do not pursue college education. Thus, it is important to examine factors that may affect self-efficacy among late adolescent in Iran.

\section{Methods}

\subsection{Participants}

The sample of this study consists of 374 late adolescents (260 female and 114 male), ranging in age from 17 to 19 years old $(\mathrm{M}=18.75, \mathrm{SD}=.44)$, from first semester of University of Medical Science in Hamadan, Iran. Respondents were selected by using probability proportional to size sampling technique. Requirements for participants in this study were having both biological parents and parents were primary caregiver during childhood.

\subsection{Procedure}

After obtaining approval from University of Medical Science in Hamadan, Iran, the list of first semester students aged between 17 and 19 years old was obtained from administration office. Respondents were invited via email or letter to voluntarily participate in this research. The data were collected using a self-administered questionnaire. Participants were given assurance that their information will be kept confidential. They were given appropriate amount of time to complete the questionnaire. The researcher and assistants guided the administration of the questionnaire. The respondents took about 45 minuts to complete the questionnaires.

\subsection{Measures}

\subsubsection{General Self-Efficacy}

The General Self-Efficacy Scale (GSE) developed by Schwarzer and Jerusalem (1995) was used to measure self-efficacy among late adolescents. This is a 10-items scale that assesses a general sense of perceived self-efficacy on 4-point Likert scale ranging from 1 (not at all true of me), 2 (hardly true), 3 (moderately true), and 4 (exactly true). Example of an item in the scale is "I can solve most problems if I invest the necessary effort". Total score of the general self-efficacy ranged from 10 to 40 . Higher scores reflected higher self-efficacy among respondents. The internal consistency for GSE in this study was .86.

\subsubsection{Parental Attachment}

The Inventory of Parent and Peer Attachment (IPPA) by Armsden and Greenberg (1989) was used to assess perceived quality of attachment with parents among adolescents. Attachment to the father and the mother were separately assessed using the same 25 items scale. This scale consists of three subscales, including trust (10 items), communication ( 9 items), and alienation (6 items). Score for negative items were reversed. Attachment scores for mother and father scale were calculated by aggregating the three subscale scores. Items are rated on a Likert scale, ranging from 1 (almost never or never true), 2 (seldom true), 3 (sometimes true), 4 (often true), to 5 (almost always or always true). A sample item from this scale is "My father understands me" or "My mother expect too much from me". Total score of the perceived parental attachment ranged from 25 to 125 . Higher scores reflected higher parental attachment among respondents. In this current study, Cronbach's alpha coefficients for IPPA mother scale was .91 and for father scale was .93 indicating desirable level of internal consistency of the scale.

\subsubsection{Inter-Parental Conflict}

The Children's Perception of Inter-parental Conflict Scale (CPIC) developed by Grych et al. (1992) measured inter-parental conflict. This study used only 44 items of 48 items in the scale. Four items were omitted due to possibility of distressing the respondents (Ross \& Fuertes, 2010). The scale consists of three subscales which are conflict properties, 17 items; threat to self, 14 items; and self-blame, 13 items. For each item, respondents indicates how true each statement relates to them using a three-point Likert type scale $(1=$ False, $2=$ Sort of true, 
3 = True). A sample item for this scale is "I got scared when my parents argued". Total score of the perceived inter-parental conflict ranged from 44 to 132 . Higher scores reflected higher inter-parental conflict. In the current study, Cronbach's alpha coefficients of the total CPIC was .91 indicating desirable level of internal consistency of the scale.

\section{Data Analysis}

In this cross-sectional study the data were analysed by Statistical Package for Social Sciences (SPSS) version 19. An Exploratory Data Analysis (EDA) was used to test the normality of data. Descriptive statistical analyses were used to describe the patterns for all variables. Pearson product moment correlation analysis was utilized to test the relationship between variables.

\section{Results}

The values of skewness and kurtosis for all variables (Table 1) were within the range between- 2 and +2 (Pallant, 2005), indicating no violation of the assumption of normality. In the present study respondents were between 17 and 19 years old $($ mean $=18.75, \mathrm{SD}=0.44)$. Of the 374 respondents, $69.5 \%$ were female and $30.5 \%$ were male. The mean age of the respondents' fathers was $50.66(\mathrm{SD}=7.28)$ and mean age of mothers was $45.67(\mathrm{SD}=6.27)$ A total of $97.9 \%$ of respondents were from intact families and live with both biological parents. A total of 317 (86\%) of respondents live on campus while, 57 (15.2\%) live off-campus and mostly with their parents. The results of this study revealed that respondents have high parental attachment in particular with their mothers (mean $=99.6$, $\mathrm{SD}=15.4)$ than their fathers (mean $=91.3, \mathrm{SD}=19.6)$. The mean score for inter-parental conflict equals 73.9 ( $\mathrm{SD}$ $=14.3)$ and the mean self-efficacy was $29.2(\mathrm{SD}=4.2)$. Based on the total score, majority $(79.7 \%)$ of the respondents indicated low inter-parental conflict (Table 2). Respondents of this study reported high level of self-efficacy $(81.8 \%)$.

Table 1. Normality of all study variables using skewness and kurtosis

\begin{tabular}{llllll}
\hline Scales/Subscales & N items & Mean (SD) & $\mathbf{5 \%}$ Trimed Mean & Skewness & Kurtosis \\
\hline General Self-efficacy & 10 & $29.2(4.2)$ & 29.2 & .108 & -.280 \\
Mother Attachment & 25 & $99.6(15.4)$ & 100.2 & -.611 & -.294 \\
Father Attachment & 25 & $91.3(19.6)$ & 92.1 & -.498 & -.324 \\
Inter-parental Conflict & 44 & $73.9(14.3)$ & 74.0 & -.029 & -1.031 \\
\hline
\end{tabular}

Table 2. Mean, standard deviation and distribution of respondents by categories of all variables

\begin{tabular}{lcccc}
\hline Variables & Min & Max & $\mathbf{n}$ & \% \\
\hline Mother attachment & 53 & 125 & & \\
$\quad$ Low level (25-74) & & & 27 & 7.2 \\
High level (75-125) & 31 & 125 & 347 & 92.8 \\
Father attachment & & & 72 & 19.3 \\
$\quad$ Low level (25-74) & & & 302 & 80.7 \\
High level (75-125) & 44 & 104 & & \\
Inter-parental conflict & & & 79 & 79.7 \\
$\quad$ Low level (44-87) & 10.0 & 40.0 & & 20.3 \\
High level (88-132) & & & 68 & 18.2 \\
Self-efficacy & & & 306 & 81.8 \\
Low level (10-25) & & & \\
High level (26-40) & & & & \\
\hline
\end{tabular}

Note: $\mathrm{M}=$ Mean; $\mathrm{SD}=$ Standard Deviation; Min = Minimum; Max = Maximum.

Pearson Product-Moment was utilized to determine the relationships between parental attachment, inter-parental conflict and adolescents' self-efficacy. Table 3 indicated that there is a significant positive correlation between mother attachment $(\mathrm{r}=.35, p<.01)$ and father attachment $(\mathrm{r}=29, p<.01)$ with self-efficacy. Furthermore results 
found a significant negative relationship between Inter-parental conflict $(\mathrm{r}=-.22, p<.01)$ and self-efficacy. The results are consistent with previous research (Bandura, 1986; Bilgin, 2011; Coleman, 2003; Karavalis, Doyle, \& Markiewicz, 2003). Adolescent with high perceived parental attachment and low inter-parental conflict tend to exhibit higher sense of self-efficacy believe. In another words, adolescent who perceived high inter-parental conflict within family environment reported lower adolescent-parent attachment and self-efficacy. Inter-parental conflict may reduce adolescent attachment to both parents which may contribute to low parent-adolescent relationship (Amato \& Sobolewski, 2001; Canary \& Canary, 2013; Ross \& Fuertes, 2010).

Table 3. Correlation matrix for all the variables

\begin{tabular}{lllll}
\hline Variables & 1 & 2 & 3 & 4 \\
\hline 1-Self-efficacy & - & & & \\
2-Mother Attachment & $.356^{* *}$ & - & - & \\
3-Father Attachment & $.299^{* *}$ & $.545^{* *}$ & $-.539^{* *}$ & - \\
4-Inter-parental Conflict & $-.223^{* *}$ & $-.455^{* *}$ & \\
\hline
\end{tabular}

Note: $* * p<0.01$ (1-tailed).

\section{Discussion and Conclusion}

The aim of this study was to determine the influence of parental attachment and inter-parental conflict on self-efficacy among late adolescents in Hamadan, Iran. The findings of this study indicated a statistically significant correlation between both mother and father attachment and self-efficacy among late adolescents. Adolescents who have high attachment to parents tend to exhibit higher level of self-efficacy. The results of this study is consistent with previous research indicating that secure attachment to mother and father enhanced adolescent's ability in social situation and positively promote self-efficacy (Arbano \& Power, 2003; Bilgin, 2011; Coleman, 2003; Malinckrodt, 1992). The result of this study also showed that self-efficacy has stronger correlation with mother than father's attachment. When adolescent attachment system is threatened, usually adolescent turns to mother as a primary secure base (Grossman et al., 2002). During stressful situation late adolescent may reestablish attachment security with their mother to make a model in their own interpersonal relationships and maintain attachment security (Ross \& Fuertes, 2010).

Moreover, findings of this study demonstrated statistically significant negative relationships between Inter-parental conflict and self-efficacy. Adolescents who experienced more conflict between parents tend to exhibit lower self-efficacy. Researchers (Banyard \& Cross, 2008; Cui, Conger, \& Lorenz, 2005) indicated that adolescent who reported high inter-parental conflict may develop lower sense of confidence and mastery experience, which may boost adolescent possibility for negative psychological health. The results also coincide with pervious research which illustrated that aggressive relationship between parents may reduce security attachment between adolescent and parents (Amato \& Sobolewski, 2001). However, the negative effect of inter-parental conflict may diminish when there is a strong relationship between parents and adolescent (Ross \& Fuertes, 2010).

The findings of this study should be interpreted in relation to the limitations of the study. First, this study is cross-sectional and can not explain causal relationships between variables. Second, this is self-report administration and may contain some kind of bias. Third, the populations of study were late adolescents in University of Medical Science in Hamadan, Iran. Therefore, the result of this study cannot be generalized beyond this population. Finally, in this study majority of respondents were female. Previous studies (DeFranc \& Mahalik, 2002; Ross \& Fuertes, 2010; Sprecher \& Sedikides, 1993) indicated that female express themselves more than men and reported more attachment to their families which may have an effect on the result of the study.

Despite of the limitations, this study attempted to identify factors contributing to adolescent's self-efficacy. Further research is needed to examine the relationship between parental conflict and parental attachment with self-efficacy among adolescents of different age range and from various family structures. 


\section{References}

Allen, J. P., \& Land, D. (1999). Attachment in adolescence. In J. Cassidy, \& P. R. Shaver (Eds.), Handbook of attachment: Theory, research, and clinical applications (pp. 319-335). New York: The Guilford Press.

Amato, P. R., \& Sobolewski, J. M. (2001). The effects of divorce and marital discoud on adult children's psychological well-being. American Sociological Review, 66, 900-921. http://dx.doi.org/10.2307/3088878

Arbana, C., \& Power, T. (2003). Parental attachment, self-esteem and antisocial iors among African American, European American, \& Mexican American adolescents. Journal of Counseling Psychology, 50(1), 40-51. http://dx.doi.org/10.1037/0022-0167.50.1.40

Armsden, G. C., \& Greenberg, M. T. (1989). The inventory of parent and peer attachment. Preliminary test manual. Seattle: University of Washington, Department of Community Health Care Systems.

Azimi, H., Jannati, Y., \& Mahmoudi, G. (2002). Text of mental health nursing (pp. 118-129). Tehran: Salami Publication (Persian).

Bandura, A. (1986). Social foundations of thought and action: A social cognitive theory. Englewood Cliffs, NJ: Prentice Hall.

Bandura, A. (1989). Social cognitive theory. In R. Vista (Ed.), Annals of child development: Six theories of child development (Vol. 6, pp. 1-60). Greenwich, CT: JAI Press.

Bandura, A. (1994). Self-efficacy. In V. S. Ramachaudran (Ed.), Encyclopedia of Human Behavior (Vol. 4, pp. 71-81). New York: Academic Press.

Bandura, A. (1997). Self-efficacy: The exercise of control. New York: W. H. Freeman.

Bandura, A., Barbaranelli, C., Caprara, G. V., \& Pastorelli, C. (1996). Multifaceted impact of self-efficacy beliefs on academic functioning. Child Development, 67(3), 1206-1222. http://dx.doi.org/10.2307/1131888

Banyard, V., \& Cross, C. (2008). Consequences of teen dating violence: Understanding intervening variables in ecological context. Violence Against Women, 14(9), 998-1013. http://dx.doi.org/10.1177/1077801208322058

Belsky, J. (2002). Developmental Origins of Attachment Styles. Attachment and Human Development, 4, 166-170. http://dx.doi.org/10.1080/14616730210157510

Bilgin, M. (2011). Relations among proposed predictors and outcomes of social self-efficacy in Turkish late adolescents. Ç.Ü. Eğitim Fakültesi Dergisi, 40, 1-18.

Bowlby, J. (1982). Attachment and Loss: Attachment (2nd ed.). New York: Basic Books.

Buehler, C., Lange, G., \& Franck, K. L. (2007). Adolescents' cognitive and emotional responses to marital hostility. Child Development, 78, 775-789. http://dx.doi.org/10.1111/j.1467-8624.2007.01032.x

Burns, A., \& Dunlop, R. (2002). Parental marital quality and family conflict: Longitudinal effects of adolescents from divorcing and non-divorcing families. Journal of Divorce and Remarriage, 37, 57-74. http://dx.doi.org/10.1300/J087v37n01_04

Canary, H. E., \& Canary, D. J. (2013). Family conflict managing the unexpected. Oxford: Polity press.

Caprara, G. V., Steca, P., Cervone, D., \& Artistico, D. (2003). The contribution of self-efficacy beliefs to dispositional shyness: On social-cognitive systems and the development of personality dispositions. Journal of Personality, 71(6), 943-970. http://dx.doi.org/10.1111/1467-6494.7106003

Clark-Lempers, D. S., Lempers, J. D., \& Ho, C. (1991). Early, middle, and late adolescents' perceptions of their relationships with significant others. Journal of Adolescent Research, 6(3), 296-315. http://dx.doi.org/10.1177/074355489163003

Coleman, P. (2003). Perceptions of parent-child attachment, social self-efficacy, and peer relationships in middle childhood. Infant and Child Development, 12, 351-368. http://dx.doi.org/10.1002/icd.316

Collins, K. A., \& Dozois, D. J. A. (2008). What are the active ingredients in preventative interventions for depression? Clinical Psychology: Science and Practice, 15, 313-330. http://dx.doi.org/10.1111/j.1468-2850.2008.00143.x

Cooper, M., Shaver, P., \& Collins, N. (1998). Attachment styles, emotion regulation, and adjustment in adolescence. Journal of Personality and Social Psychology, 75, 1380-1397. http://dx.doi.org/10.1037/0022-3514.74.5.1380 
Cui, M., Conger, R. D., \& Lorenz, F. O. (2005). Predicting change in adolescent adjustment from changes in $\begin{array}{llll}\text { marital problems. } & \text { 812-823. }\end{array}$ http://dx.doi.org/10.1037/0012-1649.41.5.812

Cummings, E. M., \& Davies, P. T. (1994). Maternal depression and child development. Journal of Child Psychology \& Psychiatry, 35, 73-112. http://dx.doi.org/10.1111/j.1469-7610.1994.tb01133.x

Davies, P. T., \& Cummings, E. M. (1994). Marital conflict and child adjustment: An emotional security hypothesis. Psychological Bulletin, 116, 387-411. http://dx.doi.org/10.1037/0033-2909.116.3.387

Davies, P. T., Harold, G. T., Goeke-Morey, M. C., \& Cummings, E. M. (2002). Child emotional security and Inter-parental conflict. Monographs of the Society for Research in Child Development, 67, 1-115. http://dx.doi.org/10.1111/1540-5834.00206

Davis, A. A. (2002). Younger and older African American adolescent mothers' relationships with their mothers and female peers. Journal of Adolescent Research, 17(5), 491-508. http://dx.doi.org/10.1177/0743558402175004

DeFranc, W., \& Mahalik, J. R. (2002). Masculine gender role conflict and stress in relation to parental attachment and separation. Psychology of Men \& Masculinity, 3(1), 51-60. http://dx.doi.org/10.1037/1524-9220.3.1.51

Egel, D., \& Salehi-Isfahani, D. (2010). Youth transitions to employment and marriage in Iran: Evidence from the school to work transition survey. Middle East Development Journal, 2(1), 89-120. http://dx.doi.org/10.1142/S1793812010000198

Endler, N. S., Speer, R. L., Johnson, J. M., \& Flett, G. L. (2001). General self-efficacy and control in relation to anxiety and cognitive performance. Current Psychology, 20(1), 36-52. http://dx.doi.org/10.1007/s12144-001-1002-7

Ferla, U., Valcke, M., \& Schuyten, G. (2008). Relationships between student cognitions and their effects on study $\begin{array}{lllll}\text { strategies. Learning and Individual Differences, } & \text { 18(2), 271-278. }\end{array}$ http://dx.doi.org/10.1016/j.lindif.2007.11.003

Fosco, G. M., \& Grych, J. H. (2008). Emotional, cognitive, and family systems mediators of children's adjustment to Inter-parental conflict. Journal of Family Psychology, 22(6), 843-854. http://dx.doi.org/10.1037/a0013809

Ghafari, M., \& Ghasemi, A. A. (2007). Origin of youth movements in Iran: Generation gap or democracy. The international journal of humanities, 14(1), 69-87.

Ghasemi, P. (2010). Negative aspects of academic failure among student. Ghodes Newspaper, Mashhad, Iran.

Goodness, K. G., Buhrmester, D., \& Jenkins, S. R. (2002). Gender differences in early adolescents' relationship qualities, self-efficacy, and depression symptoms. Journal of Early Adolescence, 22(3), 277-309. http://dx.doi.org/10.1177/02731602022003003

Grossman, K., Grossman, K. E., Fremmer-Bombik, E., Kindler, H., Scheuerer-Englisch, H., \& Zimmerman, P. (2002). The uniqueness of the child-father attachment relationship: Father's sensitive and challenging play as a pivotal variable in a 16-year longitudinal study. Social Development, 11, 307-331. http://dx.doi.org/10.1111/1467-9507.00202

Grych, J. H., \& Fincham, F. D. (1990). Marital conflict and children's adjustment: A cognitive-contextual framework. Psychological Bulletin, 108, 267-290. http://dx.doi.org/10.1037/0033-2909.108.2.267

Grych, J. H., \& Fincham, F. D. (1993). Children's appraisals of marital conflict: Initial investigations of the cognitive-contextual framework. Child Development, 64, 215-230. http://dx.doi.org/10.2307/1131447

Grych, J. H., Seid, M., \& Fincham, F. D. (1992). Assessing marital conflict from the child's perspective: The children's perception of Inter-parental conflict scale. Child Development, 63, 558-572. http://dx.doi.org/10.2307/1131346

Hazen, E., Schlozman, S., \& Beresin, E. (2008). Adolescent psychological development: A review. Pediatrics in Review, 29, 161-168. http://dx.doi.org/10.1542/pir.29-5-161

Houshmand-Neghabi, Z., \& Morshedian-Rafiee, S. (2013). Mediating effect of academic engagement in relationship between academic self-efficacy and academic achievement among adolescent in Tehran. Life Science Journal, 10(5), 393-399. 
Karavalis, L., Doyle, A. B., \& Markiewicz, D. (2003). Associations between parenting style and attachment to mother in middle childhood and adolescence. International Journal of Behavioral Development, 27(2), 153-164. http://dx.doi.org/10.1080/0165025024400015

Kenny, M. E. (1994). Quality and correlates of parental attachment among late adolescents. Journal of Counseling and Development, 72, 399-403. http://dx.doi.org/10.1002/j.1556-6676.1994.tb00957.x

Kolb, S. M., \& Griffith, A. S. (2009). I'll repeat myself, again? Empowering students through assertive communication strategies. Teaching Exceptional Children, 41(3), 32-39.

Laible, D. J., Carlo, G., \& Roesch, S. C. (2004). Pathways to self-esteem: The role of parent and peer attachment, empathy, and social behaviors. Journal of Adolescence, 27, 703-716. http://dx.doi.org/10.1016/j.adolescence.2004.05.005

Luszczynska, A., Gutierrez-Dona, B., \& Schwarzer, R. (2005). General self-efficacy in various domains of human functioning: Evidence from five countries. International Journal of Psychiatry, 40(2), 80-89.

Mallinckrodt, B. (1992). Childhood emotional bonds with parents, development of adult social competencies, and availability of social support. Journal of Counseling Psychology, 39, 453-461. http://dx.doi.org/10.1037/0022-0167.39.4.453

Marcia, J. (1991). Identity and Self-Development. In R. Lerner, A. Peterson, \& J. Brooks-Gunn (Eds.), Encyclopedia of Adolescence (Vol. 1). New York: Garland.

Markeiwicz, D., Doyle, A. B., \& Brendgen, M. (2001). The quality of adolescents' friendships: Associations with mothers' interpersonal relationships, attachments to parents and friends, and prosaically behaviors. Journal of Adolescence, 24, 429-445. http://dx.doi.org/10.1006/jado.2001.0374

Moura, O., Santos, R. A., Rocha, M., \& Matos, P. M. (2010). Children's Perception of Inter-parental Conflict Scale (CPIC): Factor Structure and Invariance across Adolescents and Emerging Adults. International Journal of Testing, 10, 364-382. http://dx.doi.org/10.1080/15305058.2010.487964

Murphy, T. E., Gaughan, M., Hume, R., \& Moore, Jr. S. G. (2010). College graduation rates for minority students in a selective technical university: Will participation in a summer bridge program contribute to success? Educational Evaluation and Policy Analysis, 32(1), 70-83. http://dx.doi.org/10.3102/0162373709360064

Oh, J. K., Lee, S., \& Park, S. H. (2011). The effects of marital conflict on Korean children's appraisal of conflict and psychological adjustment. Journal of Child and Family Studies, 20, 444-451. http://dx.doi.org/10.1007/s10826-010-9411-6

Ormrod, J. (2006). Educational Psychology Developing Learners (4th ed.). New Jersey: Pearson Education, Inc.

Pallant, J. (2005). SPSS survival manual: A step by step guide to data analysis using SPSS for windows (Vol. 15, 3rd ed.). Crow's Nest, New South Wales, Australia: Allen and Unwin.

Pryor, J. E., \& Pattison, R. (2007). Adolescents' perceptions of parental conflict: The downside of silence. Journal of Family Studies, 13, 72-77. http://dx.doi.org/10.5172/jfs.327.13.1.72

Reese-Weber, M., \& Kahn, J. H. (2005). Familial predictors of sibling and romantic-partner conflict resolution: Comparing late adolescents from intact and divorced families. Journal of Adolescence, 28(4), 479-493. http://dx.doi.org/10.1016/j.adolescence.2004.09.004

Rice, K. G., Cunningham, T. J., \& Young, M. B. (1997). Attachment to parents, social competence, and emotional well-being: A comparison of black and white late adolescents. Journal of Counseling Psychology, 44, 89-101. http://dx.doi.org/10.1037/0022-0167.44.1.89

Risdal, D., \& Singer, G. H. S. (2004). Marital adjustment in parents of children with disabilities: A historical review and meta-analysis. Research \& Practice for Persons with Severe Disabilities, 29, 95-103. http://dx.doi.org/10.2511/rpsd.29.2.95

Ross, J., \& Fuertes, J. (2010). Parental Attachment, Inter-parental Conflict, and Young Adults' Emotional Adjustment. The Counseling Psychologist, 38(8), 1050-1077. http://dx.doi.org/10.1177/0011000010376094

Rynn, M., Vidair, H., \& Blackford, J. (2012). Anxiety disorders, an issue of child and adolescent psychiatric clinics of North America (1st ed.). Elsevier Inc.

Sadeghian, E., \& Heidarian, P. A. (2009). Stressors and mental health status among students of Hamadan University of Medical Sciences. Hayat, 15(1), 71-80. 
Schulz, M. S., Waldinger, R. J., Hauser, S. T., \& Allen, J. P. (2005). Adolescents' behavior in the presence of Inter-parental hostility: Developmental and emotion regulatory influences. Developmental and Psychopathology, 17, 489-507. http://dx.doi.org/10.1017/S0954579405050236

Schwarzer, R., \& Jerusalem, M. (1995). Generalized Self-Efficacy Scale. In J. Weinman, S. Wright, \& M. Johnston (Eds.), Measures in health psychology: A user's portfolio; Causal and control beliefs (pp. 35-37). Windsor, UK: Nfer-Nelson.

Segrin, C., Taylor, M., \& Altman, J. (2005). Social cognitive mediators and relational outcomes associated with parental divorce. Journal of Social and Personal Relationships, 22(3), 361-377. http://dx.doi.org/10.1177/0265407505052441

Smetana, J. G., Campione-Bafr, N., \& Metzgef, A. (2006). Adolescent development in interpersonal and societal $\begin{array}{lllll}\text { contexts. Annual Review of 255-284. } & \end{array}$ http://dx.doi.org/10.1146/annurev.psych.57.102904.190124

Sprecher, S., \& Sedikides, C. (1993). Gender differences in perceptions of emotionality: The case of close heterosexual relationships. Sex Roles, 28, 511-530. http://dx.doi.org/10.1007/BF00289678

Statistical Center of Iran. (2010). Statistical year book of Iran. Tehran: statistical Center of Iran.

Thompson, R. (1999). Early attachment and later behavior. In J. Cassidy, \& P. R. Shaver (Eds.), Handbook of attachment: Theory, research, and clinical applications (pp. 319-335). New York: The Guilford Press.

Tillman, K. H. (2007). Family structure pathways and academic disadvantage among adolescents in stepfamilies. Sociological Inquiry, 77, 383-424. http://dx.doi.org/10.1111/j.1475-682X.2007.00198.x

Weber, J. L., \& O’Brien, M. (1999). Latino children's responses to simulated Inter-parental conflict. Cognitive Therapy and Research, 23(3), 247-270. http://dx.doi.org/10.1023/A:1018739514320

Wolf, K. A., \& Foshee, V. A. (2003). Family violence, anger expression styles, and adolescent dating violence. Journal of Family Violence, 18(6), 309-316. http://dx.doi.org/10.1023/A:1026237914406

Zajacova, A., Lynch, S., \& Espenshade, T. (2005). Self-efficacy, stress, and academic success in college. Research in Higher Education, 46(6), 677-706. http://dx.doi.org/10.1007/s11162-004-4139-z

\section{Copyrights}

Copyright for this article is retained by the author(s), with first publication rights granted to the journal.

This is an open-access article distributed under the terms and conditions of the Creative Commons Attribution license (http://creativecommons.org/licenses/by/3.0/). 